Marquette University

e-Publications@Marquette

Social and Cultural Sciences Faculty Research and

Publications

Social and Cultural Sciences, Department of

$1-1-2014$

\title{
Conflicts Within the Black Churches
}

Angelique Harris

Marquette University, angelique.harris@marquette.edu

Published version. "Conflicts Within the Black Churches" in The Oxford Handbook of Theology, Sexuality, and Gender. Ed. Adrian Thatcher. Oxford: Oxford University Press, 2014. DOI. (C) 2014 Oxford University Press. Used with permission. 


\title{
Oxford Handbooks Online
}

\section{Conflicts Within the Black Churches a}

\author{
Angelique Harris
}

The Oxford Handbook of Theology, Sexuality, and Gender

Edited by Adrian Thatcher

Print Publication Date: Nov 2014

Subject: Religion, Religious Identity, Religion and Society, Protestant Christianity

Online Publication Date: May 2014 DOI: 10.1093/oxfordhb/9780199664153.013.019

\section{Abstract and Keywords}

This essay examines conflicts concerning sex, sexuality, and gender within Black churches. Black churches are American Protestant churches with a predominantly Black leadership and congregation. Often serving the oppressed and underprivileged, Black churches have a history not only of providing for the spiritual needs of Black Americans, but also of fighting for social justice. Increasingly, controversies have begun to emerge within these churches, about gender equality, HIV/AIDS and safer sex education, and, perhaps the most controversial, about homosexuality and same-sex marriage. This essay discusses how Black churches have responded to these issues and the impact that HIV/ AIDS has had on this response. Additionally, examples of the role of women and sexual minorities in Black church denominations and congregations will be provided.

Keywords: Black churches, sexuality, sex, women, HIV/AIDS

\section{Introduction}

THIS essay examines conflicts concerning sex, sexuality, and gender within Black churches. Black churches are Protestant churches in America with a predominantly Black leadership and congregation. Black churches are based on Protestant Christian beliefs and are often rooted in the history of slavery and colonialism that Blacks from across the African diaspora have historically endured. Serving their often poor and underprivileged congregants and community members, these Black churches have a history of fighting for equality, against racial/ethnic discrimination, and for the rights of the oppressed. Within recent years, however, further controversies have arisen within these religious institutions. These controversies include gender equality, HIV/AIDS and safer sex 


\section{Conflicts Within the Black Churches}

education, and, perhaps the most controversial, the increased societal acceptance of homosexuality and same-sex marriage. This essay explores how Black churches have responded to these issues and how HIV/AIDS has influenced these responses.

Additionally, it will provide examples of the role of women and sexual minorities in Black church denominations and congregations.

\section{The Black Church Defined}

Although 'Black churches' exist throughout the world, the 'Black Church', as an institution, is uniquely American. Black churches are made up of different Protestant religious centres and houses of worship that are often grouped together into denominations that primarily consist of, and are led by, Black Americans (Lincoln and Mamiya 2003; A. Harris 2010). These Black churches make up the institution of the Black Church, which (p. 396) is the most influential social and cultural institution within Black American communities (Lincoln and Mamiya 2003).

Black churches are typically characterized by their jubilant services that often encourage worship through music, song, and dance (Lincoln and Mamiya 2003). Black churches are also known for promoting liberation theology-an interpretation of Christian beliefs that emphasizes freedom and acceptance (Cone 1996). Theologian James Cone explains, 'Black theology is a theology of liberation because it is a theology which arises from an identification with the oppressed Blacks of America, seeking to interpret the gospel of Jesus in light of the Black condition. It believes that the liberation of the Black community is God's liberation' (Cone 1996: 11). Liberation theology is a social movement that uses aspects of Christian doctrine to address social problems and injustices. Often, the concern for justice and freedom is infused in worship services, songs, and sermons. To illustrate this, religious scholars C. Eric Lincoln and Lawrence H. Mamiya (2003: 4) quote a famous Black spiritual:

Before I'll be a slave

I'll be buried in my grave

And go home to my Father

And be free...

The vast majority of Black Christian Americans are members of the original seven Black church denominations that have their origins in the struggles most Blacks endured as a result of slavery and emancipation. These denominations are the African Methodist Episcopal Church; the Christian Methodist Episcopal Church; the African Methodist Episcopal Zion Church; the National Baptist Convention, USA, Incorporated; the National Baptist Convention of America, Unincorporated; the Progressive National Baptist Convention; and the Church of God in Christ (Lincoln and Mamiya 2003). Additional Black churches include African Union First Colored Methodist Protestant Church; Fire Baptized Holiness Church of God of the Americas; Mount Sinai Holy Church of America; 


\section{Conflicts Within the Black Churches}

Spiritual Israel Church and Its Army; and the United Pentecostal Council of the Assemblies of God, Inc. Religious scholars Lincoln and Mamiya explain, 'Today, the seven major Black denominations with a scattering of smaller communions make up the body of the Black Church and it is estimated that more than 80 per cent of all Black Christians are in these seven denominations, with smaller communions accounting for an additional 6 per cent' (Lincoln and Mamiya 2003: 1). Although new Christian denominations with Black leadership continue to emerge, they often are modelled on the traditions of the seven original Black church denominations.

Highlighted in the early writings of sociologists W. E. B. DuBois (1903) and later, E. Franklin Frazier (1969), scholars have noted the significant role of the Black Church in the lives of Black Americans. Black churches served as both a safe haven and second family for Black Americans, helping to shield them from some of the trails and hardships of slavery, Emancipation, Reconstruction, and then the Great Migration from southern to northern states (Wimberly 1979). During slavery in the Americas, slave (p. 397) masters often used religion to encourage docility and obedience among the already extremely spiritual enslaved African population. Instead, Christian beliefs were reappropriated and then used as a form of resistance by emphasizing aspects of Christianity that focused on liberation and spiritual salvation (Genovese 1972). Consequently, a culture developed among Black Americans whereby religion and spirituality were used as the impetus for the fight for social justice and equality. This was further exacerbated by the fact that many Blacks, both freed and enslaved, were denied entry into public spaces and were prevented from congregating without the 'supervision' of Whites. The only exception to this was during worship services. Therefore, many plans for freedom and the abolition of slavery took place in early Black churches.

After slavery, Black churches continued to provide for the social and economic needs of Black Americans and served as the primary location for community action (Pattillo-McCoy 1998). As Blacks were still often barred from civic institutions and public spaces, the Black Church went on to serve as 'a school, a bank, a benevolent society, a political organization, a party hall, and a spiritual base' (Pattillo-McCoy 1998: 769) for many Blacks. Black churches provided an early home for political and social activists during the civil rights movement of the 1950s and early 1960s, where many Black community leaders actively fought against discrimination and Jim Crow era segregation. The history books are filled with stories of how charismatic civil rights leaders such as Martin Luther King, Jr., Joseph Lowery, Jesse Jackson, and Wyatt T. Walker used the oratory and organizing skills they learned as leaders within Black churches to organize Black community members and congregants in the struggle for civil rights.

Today, Black churches are an important space for providing and even encouraging racial and cultural pride and solidarity among Black Americans. Many churches often host neighbourhood block parties as well as social and cultural community events. Furthermore, Black churches are known for providing emotional and social support for their congregants and communities by providing soup kitchens, food pantries, health 


\section{Conflicts Within the Black Churches}

ministries, counselling, and other forms of community outreach (Ellison and Sherkat 1995).

The centrality of the Black Church in the lives of Blacks in Americans varies by gender, age, sexual orientation, marital status, education, and geography. Among Blacks in the rural South, for example, researchers Christopher G. Ellison and Darren E. Sherkat (1995) claim that the Black Church serves as a 'semi-involuntary institution' where southern Blacks are expected to join a church. Similarly, because of the Black Church's role during slavery, the effect of Jim Crow's segregation and discrimination, and the prohibition on secular gatherings in public and private spaces for Blacks, the Black Church took on a significant role in the lives of many Blacks, particularly in the South. Conversely, in major metropolitan areas, primarily in the northern states where Blacks had increased freedom, Blacks had much more of a 'voluntary' involvement with the church (Ellison and Sherkat 1995: 1416). "The availability of (1) a wider range of secular lifestyles and (2) secular sources of benefits usually provided by the church in rural southern communities may make urban religious institutions less central' (Ellison and Sherkat 1995: 1416).

(p. 398) Irrespective of geographic location, however, Black Americans are highly religious. A National Survey of Black Americans (Billingsley and Caldwell 1991: 428) found that

- 84 per cent of African American adults considered themselves to be religious

- 80 per cent considered it very important to send their children to church

- 78 per cent indicated that they pray often

- 76 per cent said that the church was a very important institution in their early childhood socialization

- 77 per cent reported that the church was still very important

- 71 per cent attended church at least once a month

- nearly 70 per cent were members of a church.

In fact, Black women are the most religious racial/ethnic group in the United States. A 2013 study conducted by the Washington Post and Kaiser Family Foundation found the following:

- 74 per cent of Black women and 70 per cent of Black men believe 'that living a religious life' is 'very important' as compared to 57 per cent of White women and 43 per cent of White men.

- 87 per cent of Black women and 79 per cent of Black men believe that 'religion or faith in God' plays a very important role 'in helping [respondents] get through tough times' as compared to 66 per cent of White women and 51 per cent of White men (Washington Post 2013). 


\section{Conflicts Within the Black Churches}

Interestingly, this survey also found that Black women had the highest rates of life satisfaction with 51 per cent reported being very satisfied with their lives, compared to 46 per cent among Black men, 50 per cent among White women, and 48 per cent among White men. These findings are not surprising as research has often noted the major influence that religion and spirituality have in providing a more positive outlook and overall physical well-being (Wilson 2000). For instance, one study indicates that Black Americans who attend church regularly, as defined by two to three times a month, are healthier than Blacks who do not attend church regularly (Wilson 2000). The mediation and optimism offered through prayer and the social support provided by worshipping in a communion with others and also by participating in social and community activism elevates the role of religion and of the Black Church in the lives of many Black Americans and communities. As such, many Black churches have routinely provided their parishioners and communities with everything from food pantries, to parish nurses who check vital signs for high blood pressure, to community health fairs. Black church pastors, religious leaders, and congregants are often even expected to visit sick and bedridden church and community members. This responsibility of caring for community members and for the sick was greatly challenged during the early years of the HIV/AIDS epidemic in Black American communities. In particular, the challenge for Black churches centred around providing care, support, and HIV education while also (p. 399) adhering to their traditional beliefs and concerns. Most of this tension centred on the Black Church's perception of sexuality.

\section{History and Sexuality}

Like most other religious institutions, the Black Church, overall, tends to take a particularly conservative stance towards issues of sex and sexuality. Black churches often promoted abstinence from sex until marriage. This belief was not only fuelled by scripture but also by the desire of the church and the middle class, primarily women, to discourage any form of sexual expression or accusations of depravity. These church folk believed that one way to increase positive perceptions of Black Americans among Whites was to promote a culture of respectability among Blacks-working class and poor Blacks in particular (Higginbotham 1993). With the exception of promoting abstinence until marriage, Black church leaders often silenced discussions of sex and sexuality in the church, with this silence reverberating into larger Black communities. Kelly Brown Douglas (2003) argues that disapproval of liberal sexual expression by Black church leaders, in large part, originated with the dehumanization of Blacks during slavery in the Americas.

Although the Black Church is not exceptional in its avoidance of explicit discussions of sex and sexuality, the reasons for such avoidance are unique. During slavery Blacks were depicted as little more than hypersexual beasts without intellect, morals, or decency who were worthy of ownership, thus justifying their enslavement to Whites (West 2001; 


\section{Conflicts Within the Black Churches}

Douglas 2003). Whites strengthened their power over Blacks by degrading both Black sexuality and the Black body (Douglas 2003; Collins 2004). To distance themselves from this negative portrayal of Black sexuality, the Black Church and Black communities took a very conservative stance towards all perceived forms of sexual deviance-such as premarital sex, out-of-wedlock births, extramarital affairs, and homosexuality (Douglas 2003). In the early twentieth century, Black reformers claimed that sexual depravity caused societal ills, such as poverty and illness (Gaines 1996). The Black Church worked to 'clean up' 'the image of Black sexuality in Black communities' (Cohen 1999: 72), by policing the Black body. In fact, a number of Black churches denounced all forms of perceived deviant behaviour, such as illicit drug use, alcohol consumption, and even dancing (Higginbotham 1993). These community leaders believed that '[r]espectability was part of a larger interracial pedagogy on earning civil rights and gaining self-respect through proper conduct' (Mitchell 2004: 85).

Therefore, this silencing of sexuality has allowed for Black communities to avoid explicit discussions of sex and sexuality. It has harboured a culture of sexual conservatism that created what Cathy Cohen (1999) referred to as a 'boundary of Blackness', whereby those groups who were perceived as being sexually deviant-such as prostitutes and homosexuals-were openly shunned within not only Black churches but also Black communities. This has had a particularly major impact on the creation of homophobia and heterosexism in Black churches and communities.

\section{(p. 400) Homosexuality}

Within many Black communities homosexuality is seen as a sexual perversion that is rooted in White society (Somerville 2000; McBride 2005; Griffin 2006). At the core of this heterosexism and homophobia is the belief among many Blacks that homosexuality did not exist in Africa prior to European contact. Many scholars have implied that homosexuality was a Western European and Arab import that colonized Africans either adopted or were forced to adopt (Johnson 2001). A number of early twentieth-century White scholars assumed that, being 'closer to nature', Blacks only practised purely heterosexual acts, mainly for the purposes of procreation, and did not practise homosexuality, which they believed was something invented by more advanced societies (Murray and Roscoe 1998). Conversely, the belief arose among some Blacks that homosexuality does not exist in African societies because African societies are more civilized and moral, and as such, too advanced for homosexual sex (Ajen 1998; Murray and Roscoe 1998).

There are countless instances of same-sex behaviour and the bending of traditional gender roles and norms in Africa. For instance, male transvestites were referred to as makhanith or mahanisi in Zanzibar and mashoga in Mombasa, and magai is the Swahili word for homosexual women and men (Amory 1998: 68). Nonetheless, each culture 


\section{Conflicts Within the Black Churches}

understood and responded to these behaviours differently and ascribed different meanings and values to them. Some cultures found them to be acceptable while others found them to be deviant (Murray and Roscoe 1998).

In his account of the history of homosexuality, David Greenberg (1990) notes that the construct of homosexuality began with the association of sex and sin. As women were not thought of as having a sexuality independent of men, female same-sex attractions have been notoriously under-examined within historical writings and accounts. Consequently, the bulk of Greenberg's work focuses on male homosexual sex and he argues that it was frowned upon as being a 'wasteful loss of semen...no different from throwing away money' (Greenberg 1990: 362). Believing in a limited supply of semen, religious leaders considered it a sin to 'spill' semen during same-sex behaviours and masturbation. Birth control was also a sin. Religious doctrine encouraged that 'intercourse between spouses should not take place too frequently' (1990: 362), and when it did occur, it should only take place for the explicit purposes of procreation. Religious leaders attempted to regulate society through their control of sex, sexuality, and procreation (Foucault 1990). Michel Foucault maintained that religious leaders believed deviant forms of sexual expression should be 'driven out, denied, and reduced to silence' (1990: 4).

Historically, in the United States, homosexuality was criminalized, perceived as a sickness, and eventually became an identity (Conrad and Schneider 1992), but among a majority of Black Americans, homosexuality became a deviant identity (ConstantineSimms 2001). Although Black church leaders routinely ignored homosexuality, there were instances whereby these leaders preached against homosexual behaviour. For example, beginning in the late 1920s Adam Clayton Powell Sr., then (p. 401) pastor of Harlem's influential Abyssinian Baptist Church, and father of Congressman Adam Clayton Powell Jr., began his well-known campaign against homosexuality by actively preaching against it and the influence he felt it was having on Black churches and communities (A. Harris 2010). Much of Powell's contention surrounding homosexuality and other forms of alleged depravity stems from what he witnessed during the Harlem Renaissance, a social and cultural movement that took place during the 1920s that was heavily influenced by the works of lesbian, gay, and bisexual artists, such as Gladys Bentley, Zora Neale Hurston, and Langston Hughes.

Pastors such as Powell often turned to passages found in the King James Version of the Bible to promote heterosexism as well as an acceptance of an open hostility towards homosexuals. As with mainstream, Western reactions to Black sexuality, where Black sexuality is treated with fascination and repulsion (West 2001), homosexuality within Black churches has received similar treatment. Many Black church leaders and congregants consider the phrase 'love the sinner, hate the sin' in their 'perceived acceptance' of homosexuality within congregations. For although they may accept 'out' lesbian and gay individuals, they may not accept the behaviour (A. Harris 2010). As premarital sex is generally frowned upon within these churches, this helps to provide justification for accepting homosexual individuals but not the behaviour (A. Harris 2010). Consequently, although today homosexuality is generally prohibited in Black churches, 


\section{Conflicts Within the Black Churches}

homosexual men in particular are, according to Fullilove and Fullilove, 'accorded a special status in many churches...[as] gay men provide creative energy necessary for the transcendent religious experience' (1997: 2). They write, 'gays in the church are responsible for creating the music and other emotional moments that bring worshippers closer to God' (1997: 2). However, they argue that these lesbian and gay church members often have to remain closeted.

Research on homosexuality in Black communities is increasingly focusing on the influential role that Black churches have in shaping the values and opinions of Black Americans towards homosexuality and other forms of sexual expression and of the impact this has on the lives of Black lesbians and gays (West 1997; Johnson 2001; A. C. Harris 2009). In the end, researchers agree that homosexuality and same-sex attractions are frowned upon among Blacks because gay men are perceived to have freely given up their male privilege-often the only privilege that Black men have (Riggs 2001)—and lesbians to have given up their femininity by not procreating with Black men (hooks 2001). Research on the Black Church and sexuality increased substantially in the early 1990s, due, in large part, to the impact of the AIDS epidemic on Black communities in the United States and abroad.

\section{AIDS and the Black Church}

Prior to the AIDS epidemic, Black churches and communities avoided open and frank discussions of sex, sexuality, and homosexuality. However, AIDS made it clear that (p. 402) acknowledging homosexuality was a matter of life and death for Blacks. Worldwide, HIV/AIDS has had a disproportionate effect on Blacks, with the greatest impact being in sub-Saharan Africa where, in countries such as Swaziland and Botswana, one out of four adults is infected with HIV (Trinitapoli and Weinreb 2012). In the United States, Black women and men make up almost half of all those with HIV/AIDS (CDC 2013). Additionally, Blacks are also significantly more likely to die from the opportunistic infections and ailments that arise as a result of AIDS (CDC 2013).

The intricacies of HIV and modes of transmission vary around the world (Trinitapoli and Weinreb 2012). For example, in sub-Saharan Africa, HIV/AIDS is a disease primarily found among heterosexuals; in the United States, although HIV is found among all populations, it is heavily concentrated among men who have sex with men-some of these men are homosexual, while others are bisexual and some identify as heterosexual (Ford et al. 2007). Most research on AIDS in Black American communities maintains that homophobia within Black communities, and especially within the Black Church, has had great implications for the perceived susceptibility of HIV infection among Blacks, particularly during the early years of the epidemic (Dalton 1989; Fullilove and Fullilove 1997; Cohen 1999; A. Harris 2010). 


\section{Conflicts Within the Black Churches}

In the early 1980s, as AIDS killed thousands in the United States and abroad, attention was placed on the four groups identified by researchers who were associated with HIV transmission-gay men, haemophiliacs, Haitians, and intravenous drug users (Shilts 1987). As AIDS in the United States was first identified among otherwise healthy gay men, gay and bisexual men were stereotyped as being the vectors of HIV, transmitting it to heterosexuals (Shilts 1987). The little information known about it concerned its almost certain mortality rates and its association with stigmatized populations. This ambiguous threat led to the further stigmatization of infected individuals. Medical personnel refused to treat those believed to be infected; HIV-positive students were turned away from schools; funeral homes even refused to bury those who died from AIDS (Cohen 1999). Although Blacks always had the highest rates of HIV/AIDS in the United States, within Black American communities AIDS was seen as a White gay disease (Cohen 1999). Consequently, believing they could not be infected, many Blacks ignored warnings from health officials allowing for rates of HIV/AIDS to increase substantially among Black Americans (Dalton 1989; Cohen 1999).

In response to these increasing rates of HIV within Black American communities, a number of Black churches have begun to openly discuss issues of sex and sexuality in an effort to provide AIDS education to their communities. Nonetheless, many churches are still reluctant to address HIV/AIDS as they fear that even mentioning HIV would draw attention to 'deviant' elements in Black communities. Additionally, many Black church leaders and congregants feared that by providing safer sex education they would suggest to congregants that they condoned such behaviours (Shelp and Sunderland 1992; Weatherford and Weatherford 1999; Douglas 2003). This response of Black church leaders to the threat of AIDS was akin to the responses of a majority of religious and social institutions in the United States and abroad during the early years of AIDS (Shilts 1987). The Black Church's reluctance to discuss AIDS was particularly hurtful for those (p. 403) living with HIV, as Black church leaders are expected to come to the aid of those who are sick and oppressed (Williams 1987; Cone 1996; Gaines 1996; Wilmore 2004). Instead, a majority of these churches not only condemned and shunned those with HIV; they actively worked to discriminate against groups associated with the virus (Cohen 1999).

Importantly, not all Black churches discriminated against those with AIDS. Some did provide support and guidance, as they recognized early on the toll that AIDS was taking on Black communities (Cohen 1999; A. Harris 2010). These churches were often in urban areas that were the hardest hit by AIDS-such as in Harlem, Brooklyn, Chicago, and Philadelphia.

Research has shown that reaching out to Black churches plays a vital role in curbing the high rates of AIDS in Black communities as it increases AIDS education and awareness and reduces stigma (Shelp and Sunderland 1992; Weatherford and Weatherford 1999; Newman 2002; Douglas 2003). AIDS education provided through Black churches has a 


\section{Conflicts Within the Black Churches}

particularly important impact on Black women, who make up a majority of Black church congregations and of HIV/AIDS cases among women in the United States (CDC 2013). 


\section{Women}

Although Black women make up a large majority of the congregants within Black churches, they are significantly less likely to hold leadership positions within these churches than their male counterparts (Gilkes 2001). Many of the reasons for this stem from both interpretations of the role of women found within religious texts and from social and cultural customs (Douglas 2003). Researchers have often noted the role that spirituality plays in the lives of Black women (Gilkes 2001; Douglas 2003; Frederick 2003). As a group who has historically endured racism, class oppression, and gender discrimination, Black women experience a unique oppression resulting in increased levels of spirituality and religiosity (Gilkes 2001). For many women in Black churches, spirituality and religion are distinct. The ethnography of Marla F. Frederick (2003), a scholar who examines religion and spirituality in the lives of Black women, found that although the women attended church regularly, prayed frequently, and believed that the church played a major role in their lives, they were sceptical of the church as well as its leadership.

As noted earlier, 74 per cent of Black women and 70 per cent of Black men believe 'that living a religious life' is 'very important' as compared to 57 per cent of White women and 43 per cent of White men (Washington Post 2013). The influence of religion and spirituality spreads to their participation within Black churches. Within Black churches women are often noted as being actively engaged in church, attending services regularly, as well as helping to lead various church ministries and outreach programmes. However, research also notes that within most Black churches women are discouraged from taking on leadership positions, such as that of a pastor (Gilkes 2001; Frederick 2003). Within (p. 404) most Black churches, ministers are allowed to teach and speak the word of the gospel to followers and congregants. Pastors, on the other hand, lead congregants and churches. Within individual Black churches pastors and to a lesser extent the church board control decisions concerning church affairs and even beliefs. Although the largest Black church denomination, the Church of God in Christ (COGIC), allows for women to function as ministers, they are barred from ordination as pastors except in extreme cases such as when the widow of the pastor is allowed to take over pastoral duties for the church in the event of her husband's death (Pitt 2012).

Other Black churches give women different routes to ordination than men (Gilkes 2001). For example, in some Black church denominations, such as the Church of the Living God (Christian Workers for Fellowship), women are required to serve as missionaries before ordination whereas men are able to be ordained without missionary duties (Gilkes 2001). The justification for not ordaining women is often rooted in the argument that since Jesus is male, only men can lead followers to God. There have been divisions within some Black church denominations concerning the role of women in these churches. For instance, angered that women could help elect bishops but not serve as bishops in the United Holy Church, many church members broke away and formed the Mount Sinai Holy Church of 


\section{Conflicts Within the Black Churches}

America (Gilkes 2001). The lack of leadership roles for women is not unique to Black churches; many of the world's largest churches such as the Roman Catholic Church and the Latter Day Saints also do not ordain women.

Black church scholar Marla Frederick (2003) describes the complex relationship that Black American women have with Black churches and explains how Black churches foster a culture of resistance as well as a culture of self-help. This tradition of resistance and self-help provides support and motivation for dealing with injustice. Frederick (2003: 7) explains that '[t]here are everyday forms of resistance that people use that do not necessarily require organizing for direct protest; nevertheless, they demonstrate opposition to the status quo or to practices with which they disagree'. Even though within many Black church denominations women cannot serve as pastors, they can still be ordained as ministers and often take on ministerial responsibilities and church governance positions.

Additionally, Black women make up a vast majority of the congregants within these churches, and as such, in reality, have access to power within these institutions (Gilkes 2001; Frederick 2003). Frederick states, 'women who work in these places do not resist politically or with confrontation; instead, in the midst of struggle, they create lives and sustain communities and develop opportunities for success (2003: 7). Even though Black churches do not often provide women with the opportunity to lead congregations, they do often encourage them to be involved in their communities (Gilkes 2001). In her discussion of the 'powerful and respected older women' in Black communities who she describes as 'community mothers' or what Patricia Hill Collins (2000) refers to as 'other mothers', Cheryl Townsand Gilkes (2001: 61) states:

In secular settings, such mothers are often the heads of Black women's organizations and hold positions of power and authority in more broadly based (p. 405) community and civil rights organizations. In sacred places...they are occasionally pastors, sometimes evangelists, more often pastors' wives and widows, but most often leaders of organized church women (missionaries, deaconesses, mothers' boards, etc.)

Thus, interestingly, Black churches, although often oppressive to women, have helped to cultivate a culture of activism among Black Americans, women in particular (Gilkes 2001). This culture of activism is evident in various activities, from addressing education and voting rights, to reproductive rights and HIV/AIDS education among Blacks (Giddens 1984; Gilkes 2001).

\section{The Black Church Moving Forward}




\section{Conflicts Within the Black Churches}

As with all religious institutions, how the Black Church responds to issues of gender, sex, and sexuality is heavily determined not only by religious doctrine but also by the unique history and culture of followers and congregants. Concerns such as women in leadership positions, same-sex marriage, and HIV/AIDS have forced some Black churches to take even more stringent stances against these issues, while allowing for other, more inclusive churches that actively welcome the emergence of women leaders as well as those with HIV/AIDS, and homosexuals. In fact, it appears as if the largest challenge to Black church traditions and norms has been the increasing presence and recognition of homosexuality. These denominations grew, in large part, because many Black lesbian, gay, bisexual, and transgender (LGBT) church and community members were forced out of their churches by unaccepting congregants and church leaders. Consequently, a number of Black churches with predominantly LGBT congregants have increased in number; the largest of these LGBT Black Church denominations is the Unity Fellowship Church of Christ.

Unity is unique in that it was founded not just as a Black church denomination, but as a social movement with the expressed purpose of responding to the impact that AIDS was having on both the physical and spiritual well-being of Blacks, and in particular, Black members of the LGBT community. As an out gay Black man who did not feel welcomed in his church, in 1982, Unity's founder, Carl Bean, a former gospel singer and Motown recording artist, began to host worship meetings in his home. Unity filled a spiritual void for many Black LGBT people who were ostracized from their churches and communities. From its inception, the work of the church was intertwined with the work of serving those affected by AIDS and HIV. Formed at a time when many churches were hostile and condemnatory towards gay men and people with HIV/AIDS, in some cases stating that their illness was God's judgement against their sexual orientation, Bean saw Unity as a vehicle to demonstrate unconditional love to those affected. This message contrasted with the hostile messages of other religious leaders and placed Unity's theology and actions firmly within the realm of liberation theology. It focuses (p. 406) on serving those who have been oppressed. Unity's core philosophies are described as follows:

Not a male dominated hierarchy; Not oppressive to women; Not just European in scope; Must relate to People of Color and their various cultures around the world; Not oppressive to Lesbian, Gay, Bi-sexual and Transgender people; Allows us to think and discern through human reason and experience; Not oppressive to Native Americans or their spirituality nor any other oppressive use of scripture; We believe in the teachings of Jesus but we DO NOT dismiss all other faiths and beliefs as wrong or second to our way of believing.

(Unity Fellowship Church Movement 2013)

Today, Unity has sixteen churches located throughout the United States. For a relatively new Black church denomination that caters to such a small demographic, the spread of Unity has been quite remarkable. In addition to Unity, other, more traditional Black churches have taken the steps to confront HIV/AIDS within Black communities and believe that the first step is to openly accept LGBT community members. Throughout the 


\section{Conflicts Within the Black Churches}

years, organizations such as 'The Balm in Gilead' worked to address this concern, helping to use Black churches as a conduit to provide AIDS education and intervention services to Black communities while also working to address homophobia in these institutions (A. Harris 2010). The Black Church Week of Prayer for the Healing of AIDS takes place during the first week of March and encourages Black churches throughout the United States to take part in AIDS education events, programmes, and sermons.

Importantly, HIV has forced many churches to openly discuss sex and sexuality. Yet, a vast majority of these churches promotes abstinence and provides abstinence-only education to its youth, even though research suggests this form of intervention is ineffective at reducing rates of HIV and other sexually transmitted infections, and also unplanned pregnancy (Hernandez and Smith 1990). Nonetheless, AIDS activists argue that at least getting these churches to talk about AIDS is the first step and is better than ignoring the HIV infection rates in Black communities (Cohen 1999; A. Harris 2010). In addition to the challenges of HIV/AIDS, Black churches have also been confronted with how they will respond to equal rights for same-sex couples.

As same-sex marriage becomes a reality in states across the United States, and the federal government's recent recognition of the rights of married same-sex couples in states that recognize these unions, many Black churches are actively rallying against these unions. Often compared to the fight for racial equality and the civil rights movement, advocates for same-sex marriage argue that not allowing legal recognition of same-sex marriage is a form of discrimination that is not only immoral but also violates constitutional law. Many Black leaders, with most stemming from Black churches, on the other hand, take offence at this comparison and argue that homosexuality is a sin, and such behaviour should not be condoned and their unions not legalized. Additionally, they fear that their religious institutions would have to acknowledge and perform such marriages.

(p. 407) The distain of Black church leaders for same-sex marriage was so great that, in 2004, Black church leaders were credited with helping to secure then President George W. Bush's re-election, based on his promise to back an amendment to the United States Constitution defining marriage as union between a man and a woman (Hutchinson 2005). Also, in California during the 2008 election season, Blacks went to the polls in record numbers to vote for Barack Obama. During the same time legislation was on the ballots reversing the legalization of same-sex marriage that had taken place several months earlier in the state. By a close margin, same-sex marriage was briefly prohibited in this state once more and many political pundits blamed Black church leaders for encouraging members to vote against same-sex marriage (DiMassa and Garrison 2008). Even as recently as 2013, Black political leaders in Illinois were hesitant to support a law legalizing same-sex marriage in the state as they feared losing the support of Black religious leaders (Stone 2013). Nonetheless, just as there have been a number of Black churches that have actively condemned same-sex marriage, there are also Black churches which have supported these unions. For example, there are some Black churches in Massachusetts and New York (states which legally recognize same-sex marriage) that do 


\section{Conflicts Within the Black Churches}

perform same-sex marriages. Furthermore, a number of Black church leaders, such as the prominent pastor of the West Point Missionary Baptist Church in Chicago, Revd Bernard Jakes, have come out in support of same-sex marriage.

\section{Conclusion}

For almost 150 years Black churches have fulfilled a great need among Black Americans. Black churches have worked tirelessly to improve the living conditions of parishioners and the members of their communities by addressing social justice concerns and providing spiritual and social support. Nonetheless, concerns that Black churches have historically grappled with, such as issues of respectability, women in leadership positions, homosexuality, and sexual promiscuity-continue to challenge church leadership. Although these issues were always addressed periodically within individual Black churches, they were not addressed in a more systematic manner until HIV/AIDS began to devastate Black communities. The direct association of AIDS with promiscuity, homosexuality, and illicit drug use barred Black church leaders from addressing AIDS. Nevertheless, a number of Black churches discovered that the devastating effect of AIDS on their congregations and larger Black communities required that they look past sex, homosexuality, and drug use to tackle the disease. This has allowed for larger Black communities to also openly address these issues. However, issues of sex, sexuality, and the role of women in these churches have always been contested and will likely continue to do so into the distant future. Only time will tell how Black churches will respond to these challenges and if they will provide women and members of the LGBT community with the same sense of justice and spiritual fulfilment they were founded to achieve.

\section{References}

Ajen, N. (1998). 'West African Homoeroticism: West African Men Who Have Sex with Men'. In Murray and Roscoe (1998), 129-140.

Amory, D. P. (1998). 'Mashoga, Mabasha, and Magai: "Homosexuality" on the East African Coast'. In Murray and Roscoe (1998), 67-90.

Billingsley, A., and Caldwell, C. H. (1991). 'The Church, the Family, and the School in the African American Community'. Journal of Negro Education, 60(3): 427-440.

CDC (Centers for Disease Control and Prevention) (2013). Health Disparities in HIV/AIDS, Viral Hepatitis, STDs, and TB. <http://www.cdc.gov/nchhstp/healthdisparities/

AfricanAmericans.html > (accessed 19 June 2013).

Cohen, C. J. (1999). The Boundaries of Blackness: AIDS and the Breakdown of Black

Politics. Chicago: University of Chicago Press. 


\section{Conflicts Within the Black Churches}

Collins, P. H. (2000). Black Feminist Thought: Knowledge, Consciousness, and the Politics of Empowerment, 2nd edn. New York: Routledge.

Collins, P. H. (2004). Black Sexual Politics: African Americans, Gender, and the New Racism. New York: Routledge.

Cone, J. H. (1996). A Black Theology of Liberation. Maryknoll, NY: Orbis Books.

Conrad, P., and Schneider, J. W. (1992). Deviance and Medicalization: From Badness to Sickness. Philadelphia: Temple University Press.

Constantine-Simms, D. (2001). 'Is Homosexuality the Greatest Taboo?' In D. ConstanceSimms (ed.), The Greatest Taboo: Homosexuality in Black Communities. Los Angeles: Alyson Books, 76-87.

Dalton, H. L. (1989). 'AIDS in Blackface'. Daedalus 118(3): 205-227.

DiMassa, C. M., and Garrison, J. (2008). 'Why Gays, Blacks are Divided on Prop. 8: For Many African Americans, It's Not a Civil Rights Issue'. Los Angeles Times, 8 November. <http://articles.latimes.com/2008/nov/08/local/me-gayblack8> (accessed 19 June 2013).

Douglas, K. B. (2003). Sexuality and the Black Church: A Womanist Perspective. Maryknoll, NY: Orbis Books.

DuBois, W. E. B. (1903). The Souls of Black Folk. Mineola, NY: Dover Publications, Inc.

Ellison, C. G., and Sherkat, D. E. (1995). "The "Semi-Involuntary Institution"-Revisited: Regional Variations in Church Participation among Black Americans'. Social Forces, 73(4): 1415-1437.

Frazier, E. F. (1969). The Negro Church in America. New York: Schocken Books.

Frederick, M. F. 2003. Between Sundays: Women and Everyday Struggles of Faith. Berkeley and Los Angeles: University of California Press.

Ford, C. L., Whetten, K. D., Hall, S. A., Kaufman, J. S., and Thrasher, A. D. (2007). 'Black Sexuality, Social Construction and Research Targeting "the Down Low"'. Annals of Epidemiology, 17(3): 209-216.

Foucault, M. (1990). The History of Sexuality: An Introduction, vol. i. New York: Vintage Books.

Fullilove, M. T., and Fullilove, R. E., III. (1997). 'Homosexuality and the African American Church: The Paradox of the "Open Closet"'. In The Balm in Gilead (ed.), Though I Stand at the Door and Knock: Discussions on the Black Church Struggle with Homosexuality and AIDS. New York: The Balm in Gilead, 1-14. 


\section{Conflicts Within the Black Churches}

Gaines, K. K. (1996). Uplifting the Race: Black Leadership, Politics, and Culture in the Twentieth Century. Chapel Hill: University of North Carolina Press.

Genovese, E. D. (1972). Roll, Jordan, Roll: The World the Slaves Made. New York: Vintage Books.

Giddens, P. (1984). When and Where I Enter: The Impact of Black Women on Race and Sex in America. New York: Perennial. (p. 409)

Gilkes, C. T. (2001). If It Wasn't for the Women. Maryknoll, NY: Orbis Books.

Greenberg, D. F. (1990). The Construction of Homosexuality. Chicago: University of Chicago Press.

Griffin, H. (2006). Their Own Received Them Not: African American Lesbian and Gays in Black Churches. Cleveland, OH: Pilgrim Press.

Harris, A. (2010). AIDS, Sexuality, and the Black Church: Making the Wounded Whole. New York: Peter Lang Publishers.

Harris, A. C. (2009). 'Marginalization by the Marginalized: The Problem of the 21st Century'. Journal of Gay and Lesbian Social Services, 21(4): 430-448.

Hernandez, J. T., and Smith, F. J. (1990). 'Abstinence, Protection, and Decision-Making: Experimental Trials on Prototypic AIDS Programs'. Health Education Research, 5(2): 309320.

Higginbotham, E. B. (1993). Righteous Discontent: The Women's Movement in the Black Baptist Church, 1880-1920. Cambridge, MA: Harvard University Press.

hooks, b. (2001). 'Homophobia in Black Communities'. In D. Constance-Simms (ed.), The Greatest Taboo: Homosexuality in Black Communities. Los Angeles: Alyson Books, 67-75.

Hutchinson, E. O. (2005). 'Black Evangelicals: Bush's New Trump Card'. AlterNet, 26 January. <http://www.alternet.org/story/21096/ black_evangelicals\%3A_bush's_new_trump_card> (accessed 19 June 2013).

Johnson, E. P. (2001). 'Feeling the Spirit in the Dark: Expanding Notions of the Sacred in the African American Gay Community'. In D. Constance-Simms (ed.), The Greatest Taboo: Homosexuality in Black Communities. Los Angeles: Alyson Books, 88-109.

Lincoln, C. E., and Mamiya, L. H. (2003). The Black Church in the African American Experience. Durham, NC: Duke University Press.

McBride, D. (2005). Why I Hate Abercrombie and Fitch. New York: New York University Press. 


\section{Conflicts Within the Black Churches}

Mitchell, M. (2004). Righteous Propagation: African Americans and the Politics of Racial Destiny after Reconstruction. Chapel Hill: University of North Carolina Press.

Murray, S. O., and Roscoe, W. (1998) (eds). Boy-Wives and Female Husbands: Studies of African Homosexualities. New York: St Martin's Press.

Newman, S. (2002). Oh God!: A Black Woman's Guide to Sex and Spirituality. New York, NY: The Ballantine Publishing Group.

Pattillo-McCoy, M. (1998). 'Church Culture as a Strategy of Action in the Black Community’. American Sociological Review, 63: 767-784.

Pitt, R. N. (2012). Divine Callings: Understanding the Call to Ministry in Black Pentecostalism. New York: New York University Press.

Riggs, M. (2001). 'Black Macho Revisited: Reflections of a SNAP! Queen'. In R. P. Byrd and B. Guy-Sheftall (eds), Traps: African American Men on Gender and Sexuality, Bloomington, IN: Indiana University Press, 292-296.

Shelp, E. E., and Sunderland, R. H. (1992). AIDS and the Church: The Second Decade. Louisville, KY: Westminster/John Knox Press.

Shilts, R. (1987). And the Band Played On. New York: Penguin Group.

Somerville, S. B. (2000). Queering the Color Line: Race and the Invention of Homosexuality in American Culture. Durham, NC: Duke University Press.

Stone, G. R. (2013). 'Same-Sex Marriage in Illinois: The Role of the Black Church'. Huffington Post, 1 June. <http://www.huffingtonpost.com/geoffrey-r-stone/same-sexmarriage-in-illi_b_3372938.html> (accessed 2 Jan. 2014).

Trinitapoli, J., and Weinreb, A. (2012). Religion and AIDS in Africa. New York: Oxford University Press. (p. 410)

Unity Fellowship Church Movement (2013). What We Believe. <http:// www.unityfellowshipchurch.org/mainsite/?page_id=7> (accessed 19 June 2013).

Washington Post (2013). 'Washington Post-Kaiser Family Foundation poll of Black women in America. Washington Post, 19 June. <http://www.washingtonpost.com/wpsrv/special/nation/black-women-in-america> (accessed 19 June 2013).

Weatherford, R. J., and Weatherford, C. B. (1999). Somebody's Knocking at Your Door: AIDS and the African-American Church. New York: Haworth Pastoral Press.

West, C. (2001). “Black Sexuality: The Taboo Subject.” In R. P. Byrd and B. Guy-Sheftall (eds), Traps: African American Men on Gender and Sexuality. Bloomington, IN: Indiana University Press, 301-307. 


\section{Conflicts Within the Black Churches}

West, C. (1997). 'The Black Church Beyond Homophobia'. In The Balm in Gilead (ed.), Though I Stand at the Door and Knock: Discussions on the Black Church Struggle with Homosexuality and AIDS. New York: The Balm in Gilead, 15-22.

Williams, J. (1987). Eyes on the Prize: American's Civil Rights Years 1954-1965. New York: Penguin Books.

Wilmore, G. S. (2004). Black Religion and Black Radicalism: An Interpretation of the Religious History of African Americans. Maryknoll, NY: Orbis Books.

Wilson, L. C. (2000). 'Implementation and Evaluation of Church-Based Health Fairs'. Journal of Community Health Nursing, 17 (1): 39-48.

Wimberly, E. P. (1979). Pastoral Care in the Black Church. Nashville: Abingdon. 